\title{
Assessment of the environmental quality of the Cachoeirinha- Invernada watershed, Guarulhos municipality (State of São Paulo, Brazil), as an urbanization reflex
}

\author{
Reinaldo Romero VARGAS ${ }^{1}$, Antonio Roberto SAAD², Fabrício Bau DALMAS ${ }^{3}$, Regina de \\ Oliveira Moraes ARRUDA ${ }^{3}$ \& Anderson Targino da Silva FERREIRA ${ }^{3}$ \\ 1 Faculdade de Tecnologia, Fatec Victor Civita, Unidade Tatuapé. Rua Antônio de Barros, 800, CEP 03401 - \\ 000, São Paulo, SP, Brasil (rei_vargas@terra.com.br). \\ 2 Instituto de Geociências, Universidade de São Paulo. Rua do Lago, 562, CEP 05508-080, São Paulo, SP, \\ Brasil (saadhome@uol.com.br). \\ 3 Programa de Pós-Graduação em Análise Geoambiental, Universidade Universus Veritas Guarulhos. \\ Praça Tereza Cristina, 229, Centro, CEP 07023-070, Guarulhos, SP, Brasil (fdalmas@prof.ung.br, \\ rarruda@prof.ung.br, atargino@prof.ung.br).
}

\begin{abstract}
The urbanization of the southeastern and southern regions of Brazil has been characterized by the lack of geotechnical planning, which has caused a series of natural disasters induced by anthropic interference. The objective of this paper is the environmental quality analysis of the Cachoeirinha Invernada Watershed, located in the city of Guarulhos. For this analysis, a survey of the geological and geomorphological conditions was carried out, an interpretative analysis of the map of land use and occupation and the quality of surface water, a survey of the urban sanitation system, as well as verification of the application of legislation environmental. The results obtained in this study attest that the Cachoeirinha-Invernada Watershed is largely degraded, due to urbanization characterized by high occupation densities in hills and valleys, terrains in which the physical environment is very fragile for such demand. The main evidences of geologic processes correspond to soil degradation by erosion, mass movements and flooding, including siltation of valleys. The occupation of the Permanent Preservation Area takes place on top of the hills, high declivity areas, stream margins and springs. The lack of sanitary sewers linked to the sewer network, the disposal of wastewater directly in streams and ditches, besides the inadequate disposal of solid waste have contributed to the low environmental quality assessed in the Cachoeirinha-Invernada Watershed.
\end{abstract}

Keywords. Water pollution, Land use, Basic sanitation, Environmental degradation.

Resumo. AVALIAÇÃO DA QUALIDAdE AMBIENTAL DA BACIA HIDROGRÁFICA CACHOEIRINHAINVERNADA, MUNICÍPIO DE GUARULHOS (ESTADO DE SÃO PAULO, BRASIL), COMO UM REFLEXO DE URBANIZAÇÃo. A urbanização das regiões sudeste e sul do Brasil tem sido caracterizada pela falta de planejamento geotécnico, o que causou uma série de desastres naturais induzidos pela interferência antrópica. 0 objetivo deste trabalho é a análise da qualidade ambiental da Bacia Hidrográfica Cachoeirinha Invernada, localizada no município de Guarulhos. Para tal análise, foram realizados: levantamento das condicionantes geológicas e geomorfológicas, análise interpretativa do mapa de uso e ocupação da terra e da qualidade das águas superficiais, levantamento do sistema urbano de saneamento básico, bem como a verificação da aplicação da legislação ambiental. Os resultados obtidos atestam que a Bacia Hidrográfica CachoeirinhaInvernada está amplamente degradada, devido à urbanização caracterizada por altas densidades de ocupação em morros e vales, terrenos em que o ambiente físico é muito frágil para tal demanda. As principais evidências dos processos geológicos correspondem à degradação do solo por erosão, movimentos de massa e inundações, incluindo o assoreamento dos vales. As ocupações de Áreas de Preservação Permanente ocorrem no topo das colinas, áreas com grande declividade, margens de riachos e nascentes. A falta de esgotos sanitários ligados à rede de esgotos, o descarte de efluentes diretamente em riachos e valas, além do descarte inadequado de resíduos sólidos contribuíram para a baixa qualidade ambiental avaliada na Bacia Hidrográfica Cachoeirinha-Invernada.

Palavras-chave. Poluição das águas, Uso da terra, Saneamento básico, Degradação ambiental. 


\section{Introduction}

In the context of Brazil's metropolitan regions, urbanization taking place with no adequate technical knowledge has caused the occupation of areas of high environmental fragility, which has led to disequilibria in the natural environment. In these cases, it is common to observe erosion, siltation, floods, which are impacts generally related to improper soil use and occupation, due to the lack of technical understanding of the environmental capabilities and weaknesses (Oliveira, 2010; Tominaga et al., 2012).

In the Brazilian southeastern region, where the concentration of economic development poles and the demographic density in urban areas are high, the transformation of cities in metropolitan regions has been characterized by the inobservance of technical planning criteria in relation to the conditioning factors of the physical and biotic environments (Mesquita, 2011).

A typical example of this process is the São Paulo Metropolitan Region (SPMR), constituted by 39 municipalities and with a population exceeding 20 million inhabitants (IBGE, 2010). Contrasting with SPMR economic robustness, materialized by expressive and diversified industrial parks, extractive activities, aerial and terrestrial infrastructures of excellence, environmental degradation is observed in the majority of the municipalities with reflexes in the quality of life as response to the undue occupation of areas not suitable to this aim (Mesquita, 2011).

Christofoletti (1996) proposed that the watershed is an appropriate unit of analysis to evaluate the environmental quality of a given region, since it is a complex environmental system that can be studied from an integrative functionality perspective. According to Botelho \& Silva (2004) the environmental quality of a watershed can be understood as reflecting the human action on space and its components at a given moment. The different levels of quality found are variable in time and space and are dependent on the demands and uses of natural resources by society. Environmental quality should be seen not only as the sum of each component of the environment, but as a condition essentially linked to the quality of life of the populations.

Evaluating the environmental quality of an urban environment is a very complex task, since there are a large number of parameters that act synergistically, varying and continuously combining the urban landscape (Lima, 2013). In addition, environmental quality is closely linked to the quality of life, since there must be an interaction and a balance between the environment and the activities that involve the human life. In an urban environment, natural (physical and biological) and anthropic (economy, culture, social relations) elements are involved and the choice of environmental parameters is not a consensus, and should occur on those that best represent the interrelationship with the quality of life. Although there is no unified method for the analysis of the environmental quality, it is observed that many studies use information about the conditions of the physical environment, basic infrastructure, demographic data and the vegetation cover (Dias et al., 2011; Bastos \& Fonseca, 2013; Ribeiro \& Mendes, 2015).

Within the subject environmental quality of watersheds, the Cachoeirinha-Invernada Watershed is the focus of this study, with areas located in the northern and southern macrocompartments. The assessment of the current environmental conditions is performed in face of the urban expansion process that has taken place in the Guarulhos Municipality since half of the 20th century. Thus, the objective of this article is to correlate the use and occupation of land, surface water quality, urban sanitation system and current environmental legislation, having as a stage of analysis the physical environment of the Cachoeirinha-Invernada Watershed (CIW), important in the appropriation of anthropic occupation.

\section{Area, materials and methods}

\section{1 Study area}

Guarulhos Municipality, which is part of RMSP and is considered the second largest city of the São Paulo State with 1.3 million inhabitants (IBGE, 2016), has owed its present development to the industrial expansion of São Paulo 
metropolis since 1950, by which time the total population was only 35 thousand inhabitants. Along these almost 70 years, as a result of the expressive population growth, the areas located in the northern portion of the municipality, which are characterized by high environmental fragility and lack of basic sanitation infrastructure, have been occupied by a low income of social segment (Oliveira et al., 2009; Mesquita, 2011).

When studying the physiography of Guarulhos, two major areas with distinct geoenvironmental characteristics are identified: the southern and northern regions, which are separated by an expressive shear zone (Andrade et al., 2008). The southern region, with a flatter topography, of easy access and where the urbanization of the municipality started, is today densely occupied by residences, commerce, industries and encompasses the Presidente Dutra Highway (BR-116), main link between São Paulo and Rio de Janeiro cities, the Ayrton Senna Highway (SP-070), and the Guarulhos International Airport. In the northern region, composed of hilly and mountainous land form unit sand several watershed areas, the anthropic occupation has been historically disordered, with informal allotments and lack of urban infrastructure, which deteriorates the environmental quality of the municipality hydric net, inserted in several hydrographic basins.

The Cachoeirinha-Invernada Watershed (CIW) is located in the northern portion of the Guarulhos Municipality, as illustrated in Figure 1. The geographical coordinates of CIW are: $46^{\circ} 29^{\prime}$ $30^{\prime \prime}$ and $46^{\circ} 31^{\prime}$ ' $35^{\prime \prime}$ 'west; $23^{\circ} 25^{\prime} 50^{\prime \prime}$ and $23^{\circ} 23^{\prime}$ $25^{\prime \prime}$ south. The study area is cross cut by a series of structural elements that are preferentially aligned in the northeastern direction, which helps subdividing itinfour structuralcompartments, with distinct physical-environmental characteristics (Chart 1, Fig. 2). The municipality of Guarulhos is cut by an important shear zone, direction $N 70^{\circ} \mathrm{E}$, which divides it into two macro-compartments, with different geological and geomorphological characteristics (Andrade et al., 2008). The macrocompartment located north of the Jaguari River shear zone, or simply, the Jaguari River Fault (Chart 1), consists of metamorphic and igneous rocks of pre-Cambrian age. In this region, Oliveira et al. (2009) recognized smaller faults pertinent to the shear zone and that imply geomorphological characteristics to the identified structural blocks. These, in turn, will be important factors in the evaluation of the areas related to the vocation for landslides, due to the high slopes towards the north. Other relevant factors are relief forms, lineaments, amplitude of relief forms, lithology and types of drainage.

It is important to emphasize that each structural compartment (Fig. 2) has characteristics of the physical environment that will compose a scenario that is sometimes unfavorable to anthropic occupation from the geotechnical point of view (Andrade, 1999).

\subsection{Environmental quality}

The environmental quality of each structural compartment identified in the Cachoeirinha-Invernada Watershed (Fig. 2, chart 1) was assessed in a holistic way, as it integrates the following geoenvironmental parameters: Land use and occupation, Urban basic sanitation system, Quality of the hydric resources and Present environmental legislation. The map of land use and occupation used was the same one obtained by Oliveira et al. (2018).

\subsection{Land use mapping}

All mapping steps were performed using the Remote Sensing techniques developed using the Spatial Analyst extension of ArcGIS, using a Pleiades sensor image (date of the flight: 08/03/2015). A pleiades sensor image has a spatial resolution of $0,5 \mathrm{~m}$. In according to Paranhos Filho et al. (2008) the produts (maps) from this imagem has a scale compatible with 1:5.000. Thus, the grafic error of Map of land use and occupation of the Cachoeirinha-Invernada Watershed is $1 \mathrm{~m}$.

The mapping was elaborated using photointerpretation and recognition of homogeneous land cover patterns. In the first step of the process was used the technique of unsupervised classification for the elaboration of the first map of use and occupation of the ground referring to the year 2015 . 

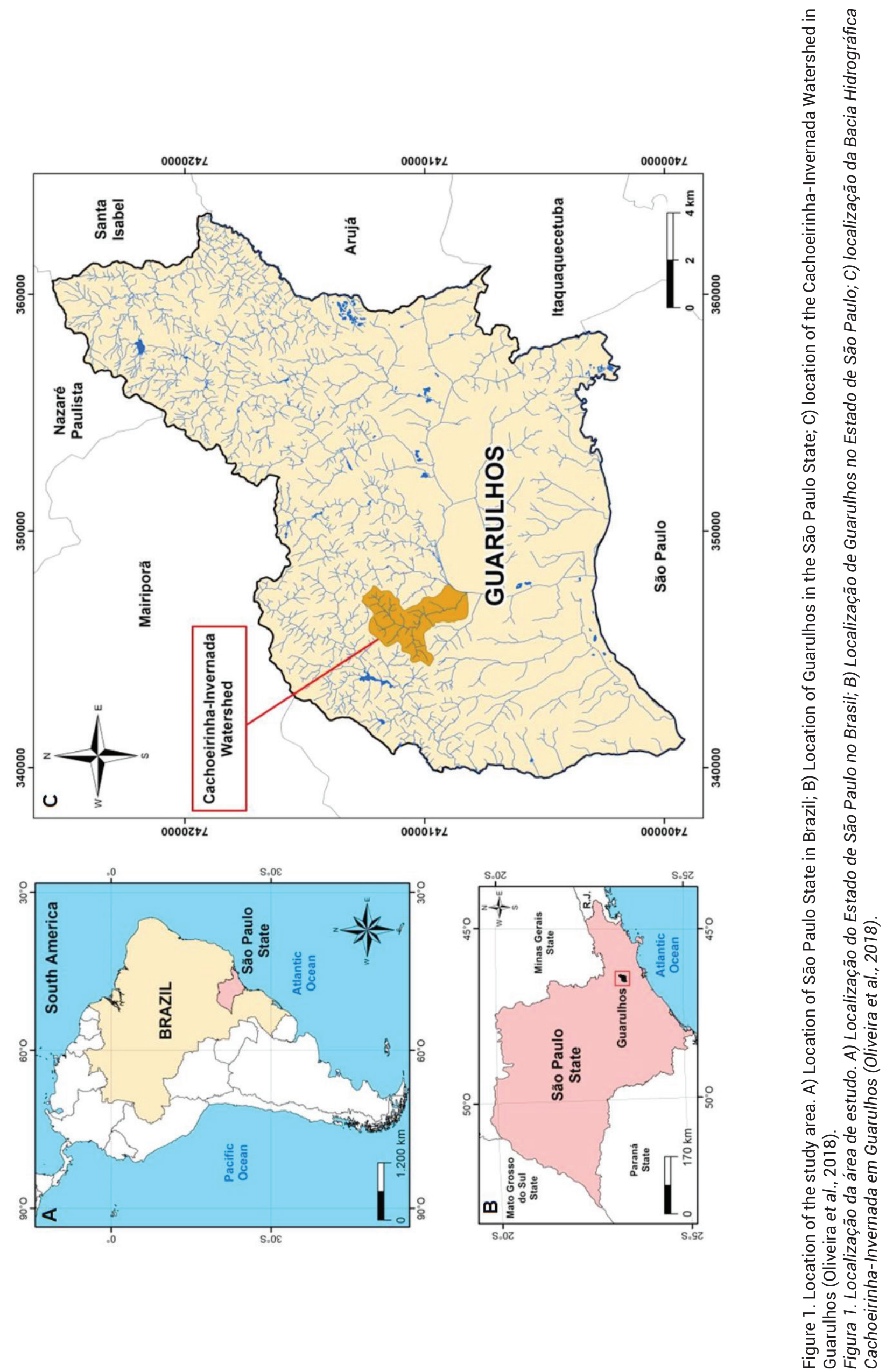
Chart 1. Characteristics of the physical environment of the Invernada-Cachoeirinha Watershed (adapted from Andrade et al, 2008; Oliveira et al., 2009; CPRM, 2015).

Quadro 1. Características do meio físico da Bacia Hidrográfica Cachoeirinha Invernada (adaptado de Andrade et al., 2008; Oliveira et al., 2009; CPRM, 2015).

\begin{tabular}{|c|c|c|}
\hline $\begin{array}{l}\text { Structural macro- } \\
\text { compartments }\end{array}$ & $\begin{array}{c}\text { Structural } \\
\text { compartments }\end{array}$ & $\begin{array}{l}\text { Predominant characteristics of the physical } \\
\text { environment }\end{array}$ \\
\hline \multirow[t]{3}{*}{ Northern } & Veigas Fault & $\begin{array}{l}\text { Landform : high hills and restricted plains } \\
\text { Drainage : high-density dendritic pattern } \\
\text { Amplitudes : } 200 \text { meters } \\
\text { Declivities : } 15 \% \text { - } 30 \% \text {; locally exceeding } \\
30 \% \\
\text { Lithologies : metapelites, metabasic rocks } \\
\text { and granite } \\
\text { Lineaments : high density } \\
\text { Soils : cambisol and latosol }\end{array}$ \\
\hline & Unnamed fault & $\begin{array}{l}\text { Landform : low hills and restricted plains } \\
\text { Drainage : high-density dendritic pattern } \\
\text { Amplitudes : } 100 \text { meters } \\
\text { Declivities : } 10 \%-30 \% \\
\text { Lithologies : granite } \\
\text { Lineaments : high density } \\
\text { Soils : latosol andgleisol }\end{array}$ \\
\hline & $\begin{array}{c}\text { III } \\
\text { Jaguari River Fault }\end{array}$ & $\begin{array}{l}\text { Landform : hillocks and restricted plains } \\
\text { Drainage : medium-density sub- } \\
\text { parallelpattern } \\
\text { Amplitudes : } 60 \text { meters } \\
\text { Declivities : up to } 30 \% \\
\text { Lithologies : metapelite } \\
\text { Lineaments : medium density } \\
\text { Soils : latosol andcambisol; gleisol }\end{array}$ \\
\hline South & IV & $\begin{array}{l}\text { Landform : mounds andamplefluvial plain } \\
\text { Drainage : sinuous and rectified channels } \\
\text { Amplitudes : up to } 20 \text { meters } \\
\text { Declivities : } 3 \% \text { - } 20 \% \\
\text { Lithologies : sandstones and conglomerates; } \\
\text { sands andclays } \\
\text { Lineaments : low density } \\
\text { Soils : gleisol and latosol }\end{array}$ \\
\hline
\end{tabular}




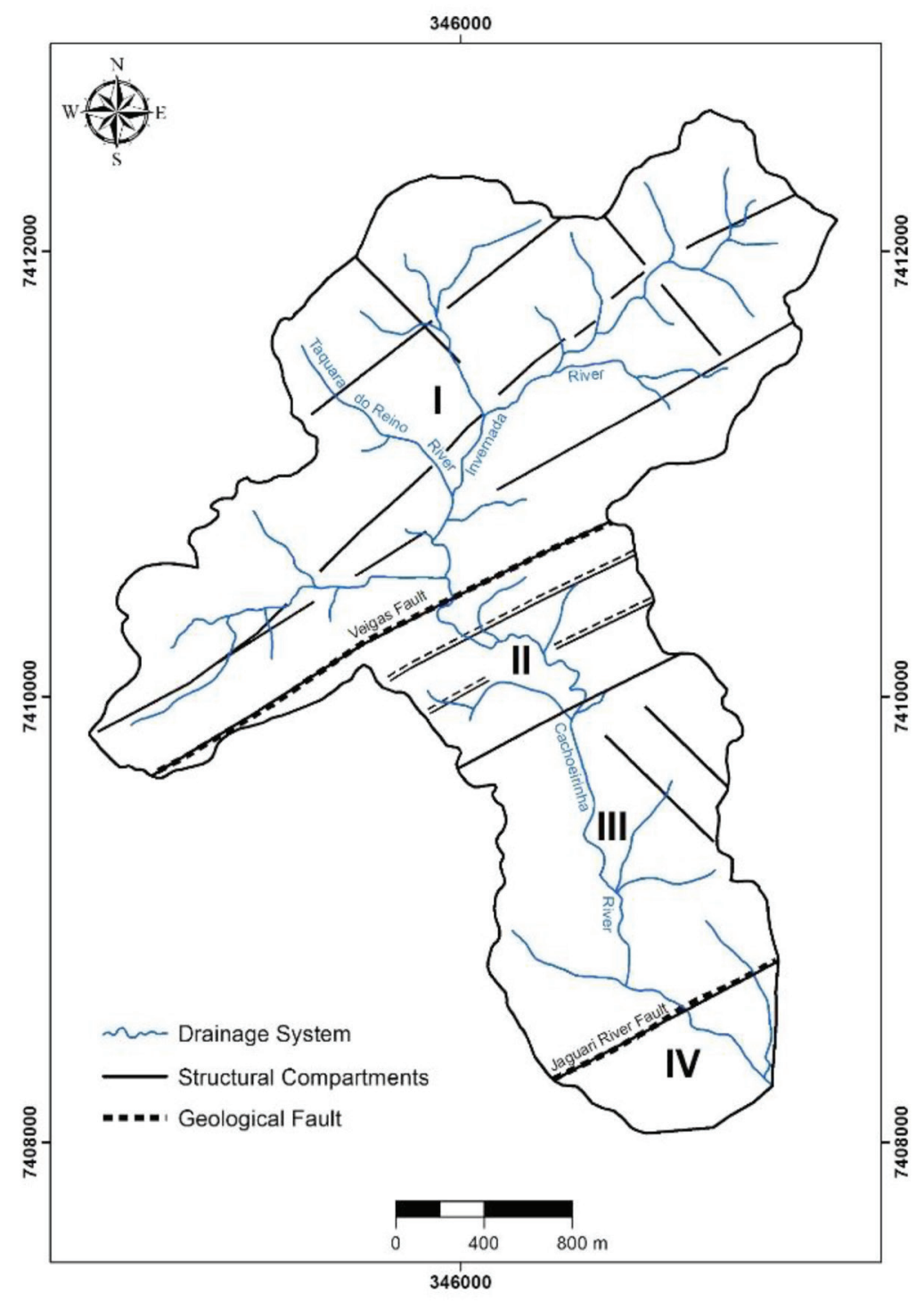

Figure 2. Drainage map and structural compartments of the Cachoeirinha-Invernada Watershed (adapted from Oliveira et al., 2009).

Figura 2. Mapa de drenagens e compartimentos estruturais da Bacia Hidrográfica Cachoeirinha Invernada (adaptado de Oliveira et al., 2009).

In the subsequent stage a Supervised classification was carried out with the purpose of refining the product acquired in the unsupervised classification, adding data collected in the field, acquired with GPS receiver (Global Position System) to register the observed points.

The Supervised classification was based on the identification of visual aspects of the observed objects, which allowed its recognition and identification. Parameters such as color, texture, geometry (shape), size, orientation and spatial distribution were considered. The urban areas were evaluated occupancy stage (level of consolidation).

\subsubsection{Urban basic sanitation system}

The thematic maps used for designing the basic urban sanitation system were obtained using the information from the Information Base of the 2010 Demographic Census: Results of the Universe by Census Sector of the Brazilian Institute of Geography and Statistics was used (IBGE, 2010). The chosen geographic unit was the Census Sectors, which is the smallest territorial unit formed by a continuous area, integrally enclosed in an urban area, of a size adequate to the operation of the research, and covering the whole study area (IBGE, 2010). 
The basic urban sanitation system including water supply, sewerage, urban cleaning, solid waste management, and rainwater drainage are indicators to the salubrity of the environment and, as a consequence, to the wellbeing of the population. (WHO, 2006; Zombini \& Pelicioni, 2014). Thus, the maps used was: i) Households with no sewer network; ii) Households with open-air sewage; iii) Households with sewerage via streams; iv) Households with sewerage via ditches; v) Households without water network; vi) Households with litter thrown in streams; vii) Households with litter in the surroundings.

\subsubsection{Quality of the hydric resources}

\subsubsection{Water sampling and analysis}

The water quality analyzes of CIW were obtained from Oliveira et al. (2018). For the analysis of the CIW water quality six points were selected for sampling (P1 to P6), which took place bimonthly from September 2015 to August 2016 (12-month period), resulting in six sample collecting campaigns. The procedures for collecting the water samples, as well as the physicochemical and microbiological analyzes, as well as the calculation of the Water Quality Index (WQI) and the Trophic State Index (TSI) were obtained from Oliveira et al. (2018).

\subsubsection{Macroinvertebrates analysis}

The macroinvertebrate analyzes used in this article were taken from Azevedo et al. (2016). For the analysis of the aquatic macroinvertebrates the samples were collected in triplicate, totalizing nine samples for each point. The macroinvertebrates were collected using a net in D with a $250-\mu \mathrm{m}$ mesh screen, as recommended by the National Guide for Collecting and Preservation of Samples (ANA, 2011). The net is placed in a proper site and the sediment up to 1 meter in front of the net is moved so that the organisms are loosened and collected by the net. The sample is conditioned in bags and fixed in $80 \%$ ethanol.

In the laboratory the organisms are classified and identified. The identification is carried out based on specific morphologic features characteristic of each family, with the aid of specific taxonomic keys and specific literature (Hamada et al., 2014).

\subsubsection{Present environmental legislation}

The mapping of the Permanent Protection Areas (PPA) of the Cachoeirinha Invernada Watershed followed the description of the Article 4 of the Law no. 12.651, of May 25, 2012 (Brasil, 2012).

\subsubsection{PPA of Water Courses}

None of the rivers and streams inside of Cachoeirinha-Invernada Watershed are more than $10 \mathrm{~m}$ wide. Thus, according to Article 4, I (a) of Law $n^{0} .12 .651 / 2012$ the PPA of water courses in the study area are a marginal strip of width of $30 \mathrm{~m}$ from the regular edge of the river. The tool "buffer" of ArcGIS (ESRI, 2011) was used to automatically delimit the PPA of water courses with vector file referring to the river layout in the scale 1:10,000, prepared by Oliveira et al. (2009).

\subsubsection{PPA of Springs}

The Article 4, IV of Law no 12.651/2012 stipulates a preservation area around springs with radius of $50 \mathrm{~m}$ regardless of the topographic situation of the area. To elaborated the mapping of PPA of Springs it was automatically generated points on the vertex of all lines that represented the rivers. Again, the tool "buffer" of ArcGIS (ESRI, 2011) was used to automatically delimit the PPA of springs of Cachoeirinha-Invernada Watershed.

\subsubsection{PPA of Declivity}

The Law 12.651/2012 (Brasil, 2012) regulates that any parts of a hillside located in a slope greater than $45^{\circ}$ is a permanent preservation area. The mapping of these areas was carried out through an analysis of the slope map of the study area. This slope map was elaborated from the topographic contour lines vector in 1:10,000 scale (Oliveira et al., 2009) that were used to generated the Digital Terrain Model (DTM) with the tool "topo to raster" of ArcGIS (ESRI, 2011). 
The spatial resolution of this DTM was 5 meters, half of the equidistance between the topographic contour lines vector used, in according to the provisions of Article 9, "a" Item 1 of Law Decree no. 89.817 of June 20, 1984 (Brasil, 1984). Keeping on in the process the slope map was drawn from the DTM with the tool "slope" of ArcGIS (ESRI, 2011). The spatial resolution of this slope map was $5 \mathrm{~m}$ too. The "reclass" tool was used to reclassify the slope map. Thus, it was possible to create two classes of slope: one class with declivity between zero and $44.9^{\circ}$; and another one with slope greater than $45^{\circ}$. This reclassified slope map was vectorized resulting in a polygon vector with two classes. The last step was to delete the declivity class with slopes lower than $45^{\circ}$.

\subsubsection{PPA of top of Hills}

The Article 4, IX of Law n. 12.651/2012 determines that areas located in the tops of hills, above height of $100 \mathrm{~m}$ in relation to the base of the hill and in average slope greater than $25^{\circ}$ are Permanent Preservation Areas. The first step to mapping the PPA of top of hills it was define which areas were above $100 \mathrm{~m}$ in relation to the base of the terrain, which is defined by the horizontal plane determined by the plain or rivers.

For this analysis it was worked on the attribute table of the topographic contour lines vector in the scale 1:10,000 (Oliveira et al., 2009). The lower height of the study area is 760 $\mathrm{m}$ in relation of sea level. Thus, this value was suppressed from all contour lines so that the minimum height would be $0 \mathrm{~m}$.

In this vector file of contour lines with new values assigned in the attribute table it was deleted all lines with a height less than $100 \mathrm{~m}$. This new vector file (only contour lines with a height of more than $100 \mathrm{~m}$ ) was applied in the tool "topo to raster" of the ArcGIS (ESRI, 2011) to develop a Digital Terrain Model (5 m of spatial resolution) of areas above height $100 \mathrm{~m}$.

A new slope map was drawn from this DMT of areas above height $100 \mathrm{~m}$, with the slope tool. The "reclass" tool was applied to reclassify the slope map and, thus, it was possible to create two classes of slope: one class with slope between zero and $24.9^{\circ}$; and another one with slopes greater than $25^{\circ}$. This reclassified declivity map was vectoralized, resulting in a polygon vector with two classes. The last step was to delete the declivity class with slopes lower than $25^{\circ}$. Thus, the map of Permanent Protection Areas of top of hills of Cachoeirinha-Invernada Watershed was elaborated.

\section{Results}

\section{1 Land use and occupation}

The land use and occupation map of the study area showed in figure 3 encompasses both rural and urban areas. The areas occupied by these land use classes are shown in table 1. In structural compartment I (Fig. 2), the class with major representativeness is the Forest Area, followed by Silviculture (Forestry), Urban Area and Pasture (Grassland). In this compartment the class Exposed Soil is represented by the Mário Covas Ring Highway - northern segment, in construction.

Table 1. Area of land use and occupation classes of the Cachoeirinha-Invernada Watershed.

Tabela 1. Áreas das classes de uso e ocupação da terra da Bacia Hidrográfica Cachoeirinha Invernada.

\begin{tabular}{lc}
\hline \multicolumn{1}{c}{ CLASS } & AREA $\left(\mathbf{K m}^{\mathbf{2}}\right)$ \\
\hline Forest & 3,05 \\
Urban area & 3,01 \\
Forestry & 0,98 \\
Exposure soil & 0,38 \\
Pasture & 0,05 \\
Agriculture & 0,04 \\
\hline
\end{tabular}

Structural compartment II (Fig. 2) is mainly represented by the Urban Area followed by Silviculture, Forest, Pasture/Grassland Areas and Agriculture. The Urban Area is predominant in Structural compartment III (Fig. 2), followed, along the Invernada stream, by the Pasture/Grassland, Forest, Agriculture and Silviculture. Structural compartment IV (Fig. 2) is almost totally covered by the Urban Area, locally occurring Pasture/ Grassland Areas.

The urban class occupies $40 \%$ of the study area (Fig. 3). The total population reaches 78,548 people, distributed in 21,862 households (IBGE, 
2010). The highest concentrations occur in structural compartments II, III and IV, whereas in structural compartment I urban occupation takes place only in the Taquara do Reino watershed (Fig. 2).

The basic sanitation system including water supply, sewerage, urban cleaning, solid waste management and rain water drainage contributes to the salubrity of the environmental, as a consequence, to the betterment of the population's health, by reducing the incidence of diseases associated with the lack of these utilities (WHO, 2006; Zombini \& Pelicioni, 2014).

The basic sanitation conditions in the CIW urbanized areas are listed in table 2.

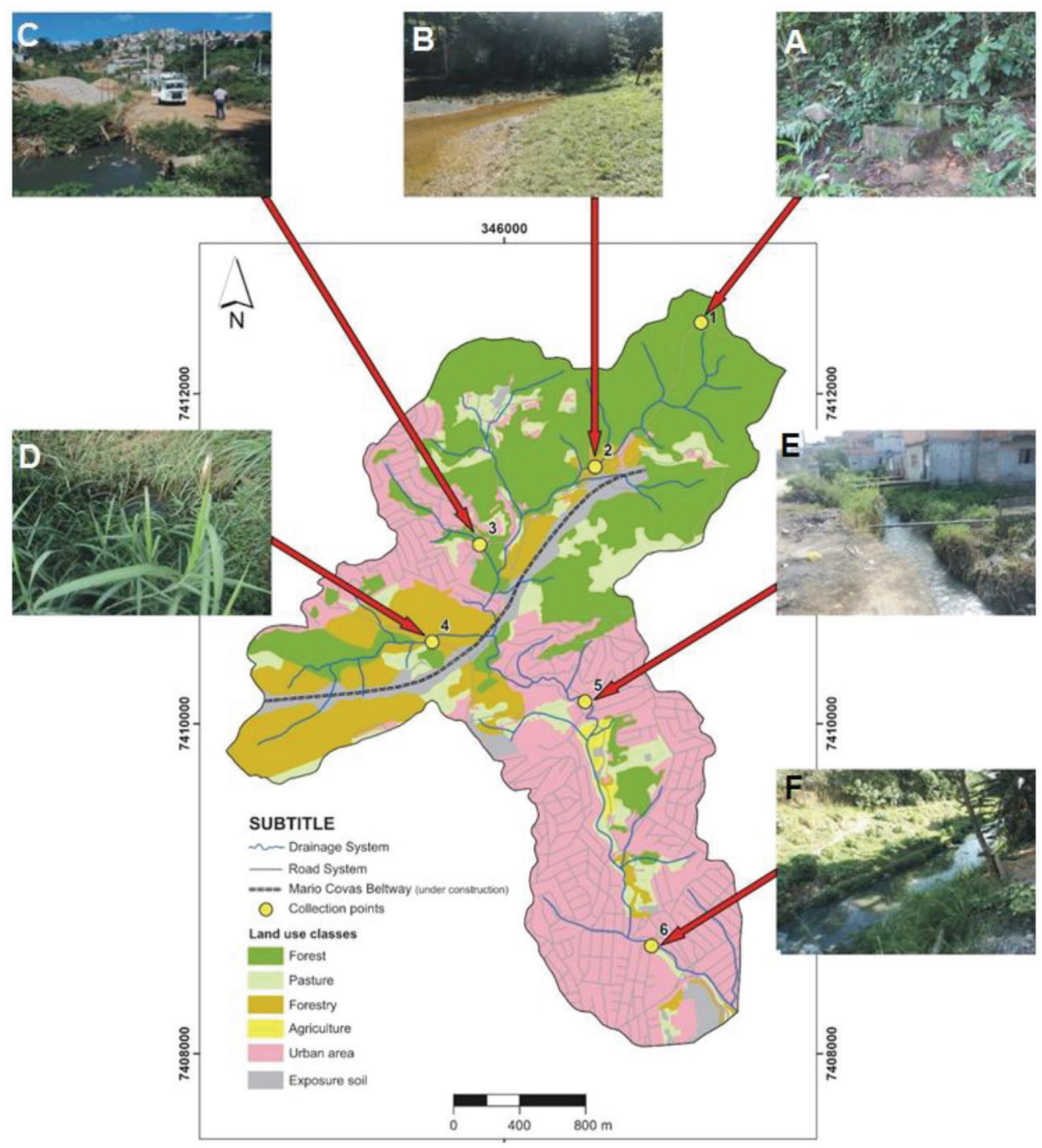

Figure 3. Map of land use and occupation classes of the Cachoeirinha-Invernada Watershed, together with respective water sampling points: A) Point 1; B) Point 2; C) Point 3; D) Point 4; E) Point 5; F) Point 6. (Adapted from Oliveira et al., 2018).

Figura 3. Mapa das classes de uso e ocupação da terra da Bacia Hidrográfica Cachoeirinha Invernada com os respectivos pontos de amostragem de águas: A) Ponto 1; B) Ponto 2; C) Ponto 3; D) Ponto 4; E) Ponto 5; F) Ponto 6. (Adaptado de Oliveira et al., 2018). 
Table 2. Basic sanitation conditions in the Cachoeirinha Invernada Watershed Urban Areas, based on IBGE (2010). Tabela 2. Condições de saneamento básico nas áreas urbanas da Bacia Hidrográfica Cachoeirinha Invernada, baseado no IBGE (2010).

\begin{tabular}{lrr}
\hline \multicolumn{1}{c}{ Households } & $\begin{array}{c}\text { Number of } \\
\text { households }\end{array}$ & $\begin{array}{c}\text { Percentage of } \\
\text { households }\end{array}$ \\
\hline with no sewer network & 3,413 & $15.61 \%$ \\
with open air sewage & 291 & $1.33 \%$ \\
with sewerage via streams & 1,609 & $7.35 \%$ \\
with sewerage via ditches & 498 & $2.27 \%$ \\
without water network & 128 & $0.58 \%$ \\
with litter thrown in streams & 23 & $0.10 \%$ \\
with litter in the surroundings & 373 & $1.70 \%$ \\
\hline
\end{tabular}

3.2 Environmental legislation - conservation units / permanent preservation areas

On the basis of the environmental legislation in force (Brasil, 2012), CIW encompasses the Cabuçu-Tanque Grande Environmental Protection Area (EPA-CTG) and several other types of Permanent Preservation Areas-PPAs.

EPA-CTG was constituted by means of the Municipal Law no. 6798/2010, aiming to establish the sustainable use of natural resources and to contemplate the betterment of the life quality of the local communities and the environmental control of anthropic occupation. In the study area the limits of this Conservation Unit coincide with those of structural compartment I.

In the terms of the present Forestry Code (Brasil, 2012), the following elements of CIW landscape, in rural or urban zones, are considered Permanent Preservation Areas (PPA).

\subsection{Mapping of Permanent Preservation Areas (PPA)}

\subsubsection{Permanent Preservation Areas of Water-} courses

There are a lot of rivers in the CachoeirinhaInvernada Watershed. Thus, part of this area $\left(1.21 \mathrm{~km}^{2}\right.$ or $16.42 \%$ of total area of watershed) is classified in according to Law 12.650 (May 25 , 2012) how permanent preservation areas. Inserted within these special areas, this watershed there are land use classes that do not match what should be there, "protected area, covered or not by native vegetation, with the environmental function to preserve water resources, landscape, geological stability and biodiversity, facilitate the genetic flow of fauna and flora, to protect the soil and ensure the well-being of human populations" (Fig. 4).

Only $48.94 \%$ of the total area of permanent preservation areas (PPA) are occupied by natural vegetation: dense arboreal vegetation (40.37\%) and ground vegetation (8.58\%). Most of the PPA area is occupied by the classes to the anthropic use, according to table 3 .

\subsubsection{Permanent Preservation Areas of Spring}

The springs have an important environmental role: they provide water for the streams and rivers that supply the whole city and are also a source of life for other organisms. In order for the springs to remain alive it is necessary to take care of the surroundings, considered

Table 3. Areas of land use classes that make up the Permanent Preservation Areas of the watercourses.

Tabela 3. Áreas de uso da terra que compõem as Áreas de Preservação Permanente dos cursos d'água.

\begin{tabular}{lr}
\hline CLASS & AREA (\%) \\
\hline Dense Arboreal Vegetation & 40.37 \\
Urbanized area & 29.07 \\
Ground vegetation & 8.58 \\
Reforestation & 15.37 \\
Exposed soil & 5.90 \\
Agricultural areas & 0.73 \\
\hline
\end{tabular}




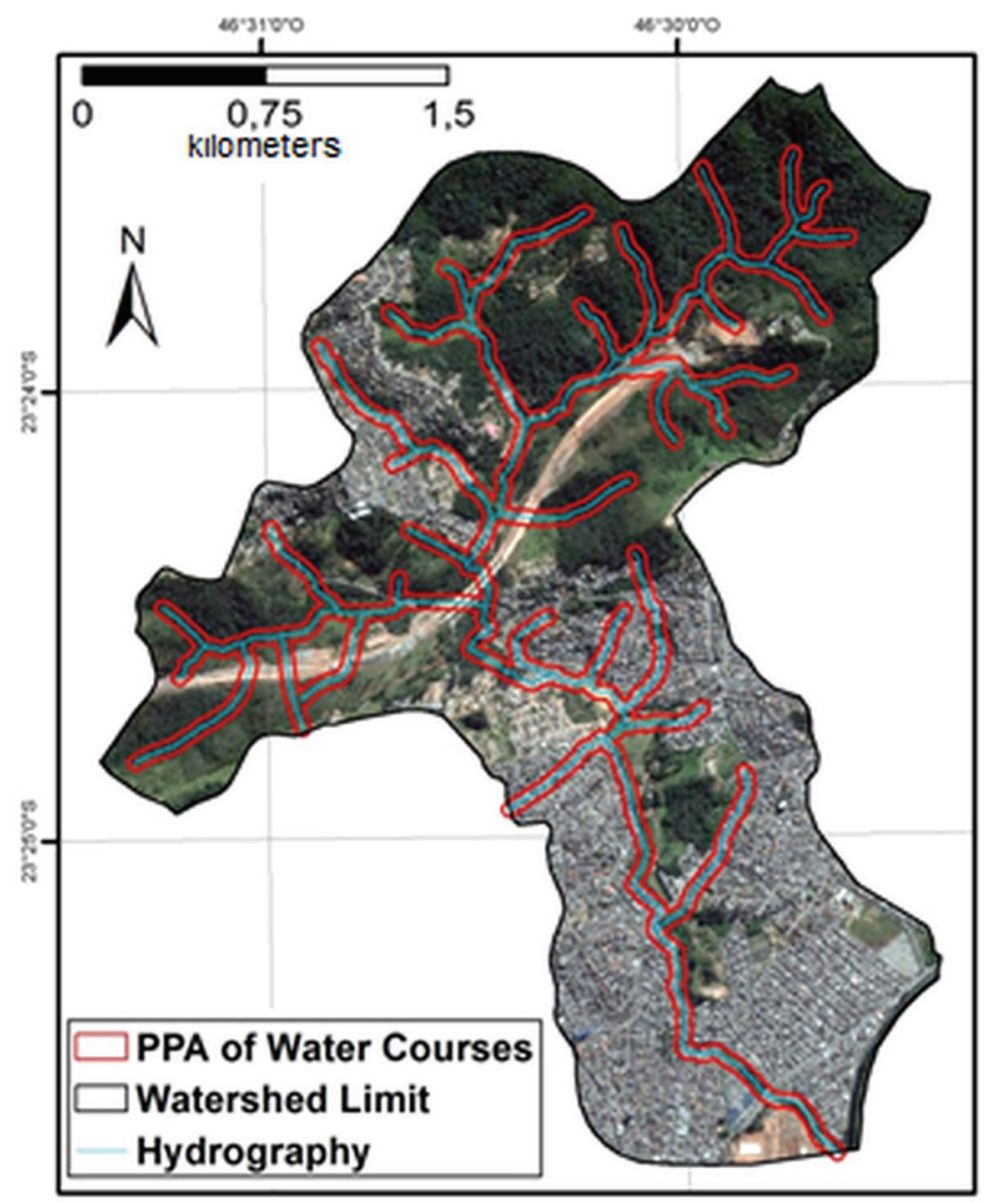

Figure 4. Permanent Preservation Areas of watercourses (vectors overlaid the Google Earth image - date of image: 08/01/2015).

Figura 4. Áreas de Preservação Permanente dos cursos de água (vetores sobrepostos à imagem do Google Earth - data da imagem: 01/08/2015).

legally as a Permanent Preservation Area (APP). If they are not preserved the springs can receive garbage and sewage and consequently several organisms present in these environments can not survive or do not develop their ecological role.

The springs are places where the aquifer appears in the land. From these points it starts the long path forming rivers and streams. Therefore, the importance of the preservation of the springs is related to the maintenance of the rivers.

The Cachoeirinha-Invernada Watershed has a rich hydrography that practically covers the whole area. The northern part of this study area (higher slopes and higher concentration of dense arboreal vegetation) is the place where there is the highest concentration of springs in this hydrographic network (Fig. 5).

The area occupied by the PPA of spring occupies only $3.25 \%$ of the total area of the watershed. Within this class of PPA where should be there only natural areas, there are classes of urbanized area, which occupies $23.30 \%$ of the total area, and exposed soil that occupying $0.79 \%$. The reforestation class that occupies $16.91 \%$ of the watershed area can cause negative impact in the springs when the planting is made mechanically, compacting the soil with heavy agricultural machinery. The area of PPA of spring occupied by natural areas is classified in Dense Arboreal Vegetation (52.39\%) and Ground vegetation (6.26\%), according to Table 4.

Table 4. Areas of land use classes that make up the Permanent Preservation Areas of the springs.

Tabela 4. Áreas de uso da terra que compõem as Áreas de Preservação Permanente das nascentes.

\begin{tabular}{lr}
\hline CLASS & AREA (\%) \\
\hline Dense Arboreal Vegetation & 52.73 \\
Urbanized area & 23.30 \\
Ground vegetation & 6.26 \\
Reforestation & 16.91 \\
Exposed soil & 0.79 \\
\hline
\end{tabular}




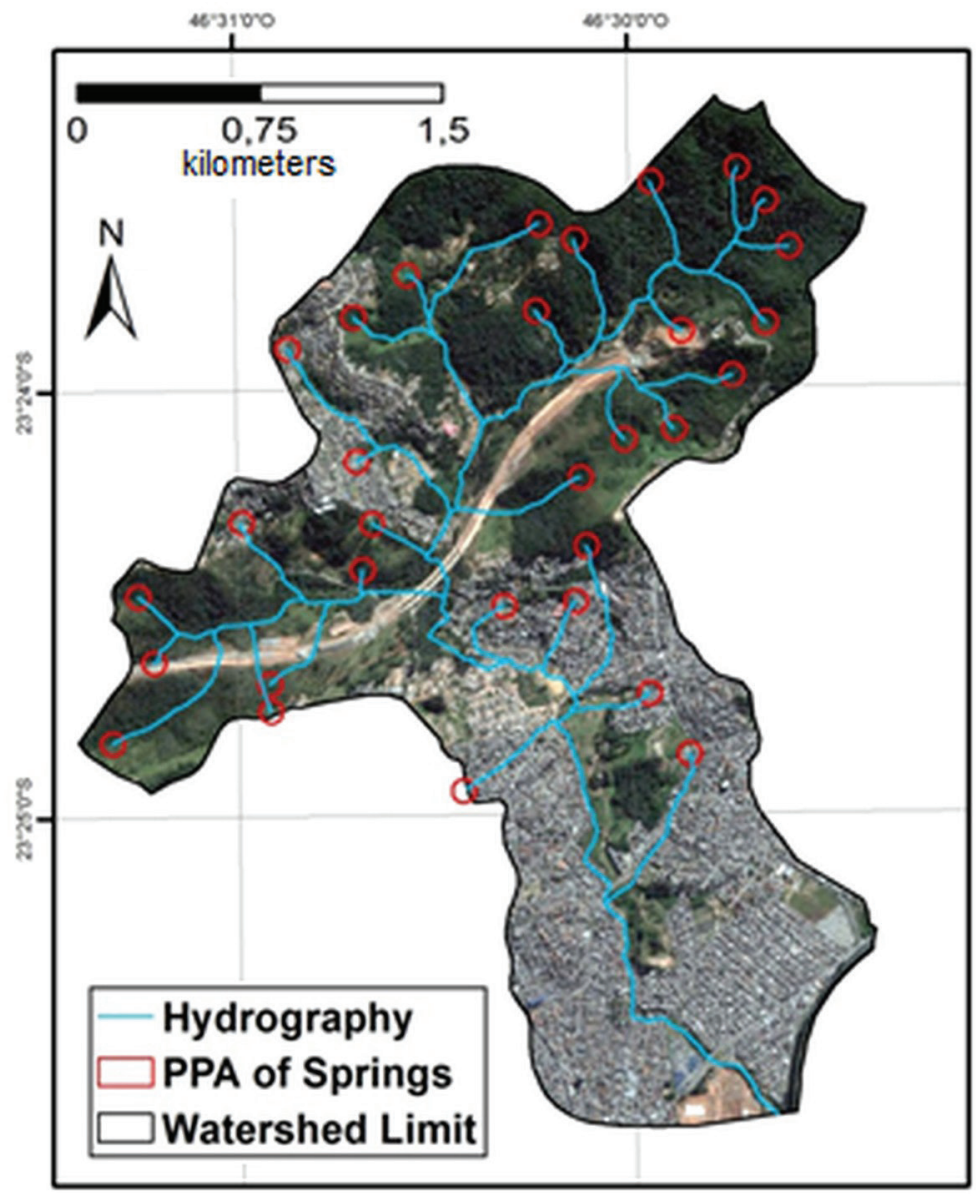

Figure 5. Permanent Preservation Areas springs (vectors overlaid the Google Earth image - date of image: 08/01/2015). Figura 5. Áreas de Preservação Permanente de nascentes (vetores sobrepostos à imagem do Google Earth - data da imagem: 01/08/2015).

\subsubsection{Permanent Preservation Areas of Declivity}

The study area presents a small number of PPA of declivity, located in the northern portion of the watershed and in some urbanized areas in the central portion of watershed (Fig. 6). These areas have the function of maintaining forest remnants along the slopes in order to avoid the potential of erosive processes and landslides, which can develop great destructive potential when in the presence of residences. This type of preservation area is occupied by dense arboreal vegetation, reforestation, urbanized area ground vegetation, according to table 5 .

\subsubsection{Permanent Preservation Areas of the Top of the Hill}

Another class of Permanent Preservation Area present in the study area is the top of the hill located mainly in the northern part of the watershed where there is predomination of
Forest. But like the same case of the PPA of declivity there is a big urbanized area inside area of top of the hills in the northwest part of watershed (Fig. 7).

This class of PPA occupies $7.10 \%$ of the total area of watershed and is mainly occupied by the Dense Arboreal Vegetation class (74.79\%). However, the class of urbanized area occupies $13.92 \%$ of the PPA area and this fact needs attention because the top of the hills are geologically fragile areas. All classes occupying the PPA of the Cachoeirinha-Invernada Watershed are in table 6.

Table 5. Areas of land use classes that make up the Permanent Preservation Areas of the Declivity.

Tabela 5. Áreas de uso da terra que compõem as Áreas de Preservação Permanente da Declividade.

\begin{tabular}{lr}
\hline CLASS & AREA (\%) \\
\hline Dense Arboreal Vegetation & 63.89 \\
Urbanized area & 15.28 \\
Ground vegetation & 1.39 \\
Reforestation & 19.44 \\
\hline
\end{tabular}




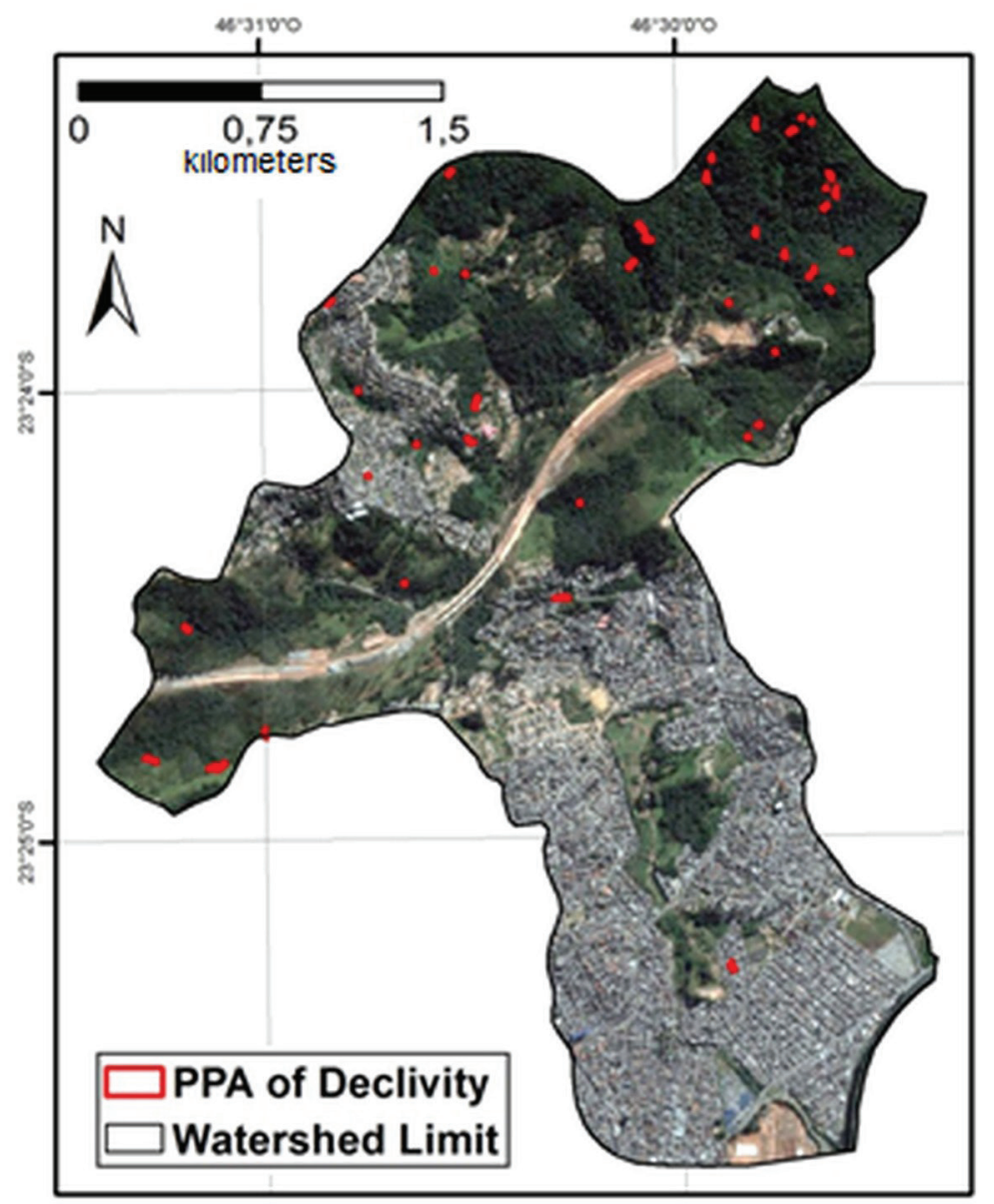

Figure 6. Permanent Preservation Areas of declivity (vectors overlaid the Google Earth image - date of image: 08/01/2015). Figura 6. Áreas de Preservação Permanente de declividade (vetores sobrepostos à imagem do Google Earth - data da imagem: 01/08/2015).

Table 6. Areas of land use classes that make up the Permanent Preservation Areas of the Top of the Hills.

Tabela 6. Áreas de uso da terra que compõem as Áreas de Preservação Permanente do Topo de Morros.

\begin{tabular}{lr}
\hline CLASS & AREA (\%) \\
\hline Dense Arboreal Vegetation & 74.79 \\
Urbanized area & 13.92 \\
Ground vegetation & 3.32 \\
Reforestation & 6.99 \\
Exposed soil & 0.97 \\
\hline
\end{tabular}

\subsection{Water quality}

As a function of land use and occupation, Azevedo et al. (2016) and Oliveira et al. (2018) selected six sampling points to assess Water Quality Index (CETESB, 2017) and Trophic State Index (CETESB, 2017) indices of the CIW tributaries, distributed along the Invernada and Cachoeirinha streams (Fig. 3).
To assess the quality of the waters and the ecologic conditions of this watershed along 12 months (September 2015 to August 2016), the authors used different parameters for the analysis. The results for these indices obtained at each analyzed point are summarized in chart 2 .

\section{Discussion}

In this section, the results obtained will be discussed in integrated terms, and presented as a function of each structural compartments, as shown in chart 1.

\section{1 Compartment I}

According to the data relative to the physical environment expressed in chart 1, several authors have classified this compartment as strongly susceptible to erosion and mass movements (landsliding and rock fall), which characterizes it as Geologically Hazardous Area (Andrade, 1999; 


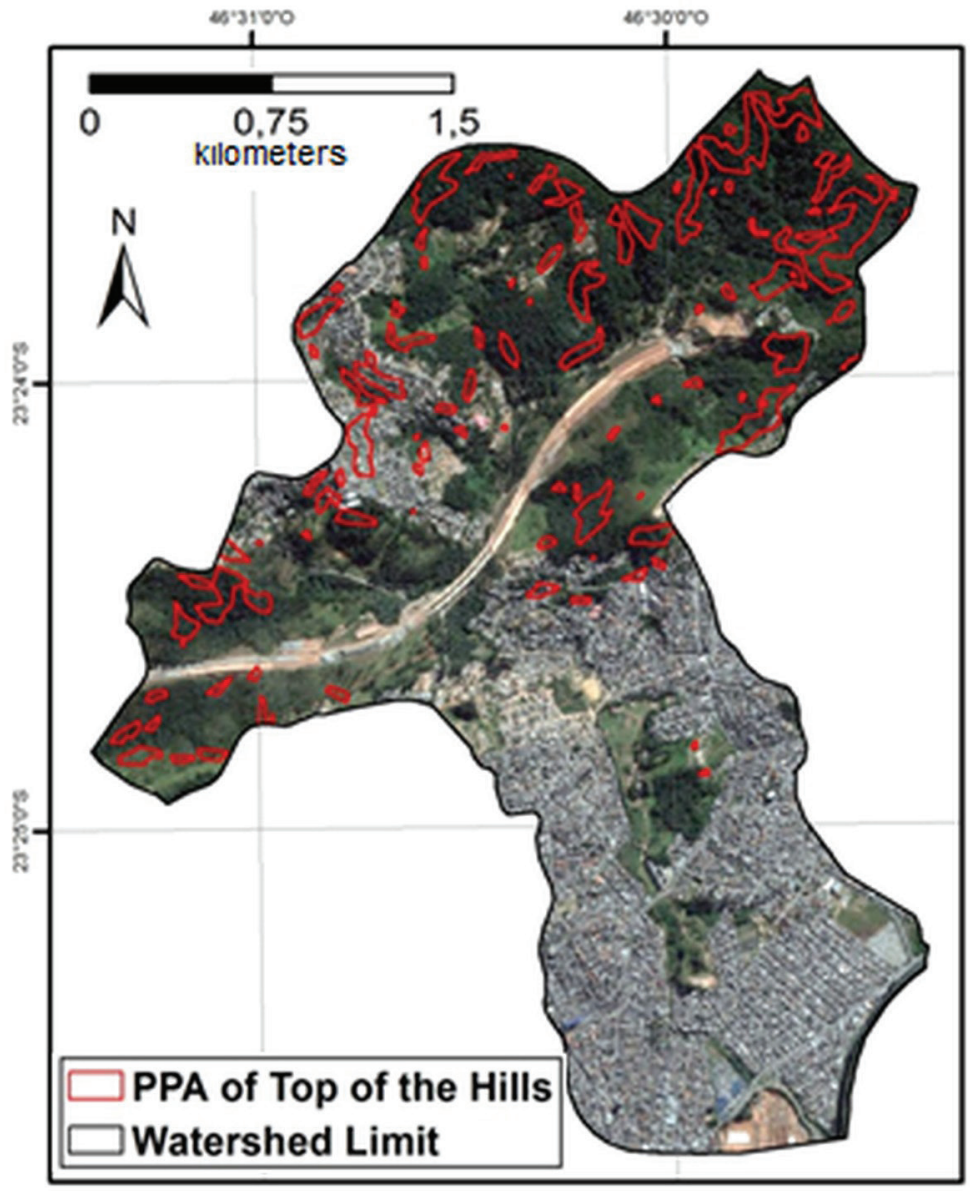

Figure 7. Permanent Preservation Areas of top of hill (vectors overlaid the Google Earth image - date of image: 08/01/2015). Figura 7. Áreas de Preservação Permanente de topo de morro (vetores sobrepostos à imagem do Google Earth - data da imagem: 01/08/2015).

Chart 2. Assessment of the quality of the waters and ecologic conditions along the analyzed points (obtained from: A) Oliveira et al., 2018; B) Azevedo et al., 2016).

Quadro 2. Avaliação da qualidade das águas e condições ecológicas ao longo dos pontos analisados (obtidos de: A) Oliveira et al., 2018; B) Azevedo et al., 2016).

\begin{tabular}{|c|c|c|c|}
\hline Point & Water Quality Index (WQI) A & Trophic State Index(TSI) A & $\begin{array}{c}\text { Benthonic Community Index } \\
\text { (BCI) B }\end{array}$ \\
\hline 1 & Good & Oligotrophic & Good \\
\hline 2 & Regular & Oligotrophic & Bad \\
\hline 3 & Bad & Super eutrophic & Bad \\
\hline 4 & Bad & Eutrophic & Bad \\
\hline 5 & Bad & Mesotrophic & Bad \\
\hline 6 & Very bad & Hypereutrophic & \\
\hline
\end{tabular}

Castro Gomes et al., 2011; Sato et al., 2011; Mesquita, 2011; CPRM, 2015).

Andrade (1999), when preparing the chart of physical adequacy to urban settling for the Guarulhos Municipality, classifies this region as a Very Restricted Area to Occupation. However, this compartment includes the urban class, represented by the Recreio São Jorge and Novo Recreio neighborhoods, occupying the Taquara do Reino microbasin since the 1970's (Sato et al., 2011). 
In these neighborhoods, the urban infrastructure is precarious when it comes to basic sanitation (Tab. 1), being more critical in Novo Recreio, where the streets are not paved and litter collection is deficient (Sato et al., 2011). As a reflex of these insalubrity conditions, the water quality assessed at point 3 is Bad (WOI) and supereutrophic (TSI), according to Oliveira et al. (2018), and Bad (ICBrio), according to Azevedo et al. (2016). Vargas et al. (2015), when analyzing the water quality along the Taquara do Reino stream, in some places upstream point 3 , obtained the same qualifications for it, corroborating the precarious sanitation conditions of these neighborhoods.

Mesquita (2011) prepared the map of environmental degradation of the Taquara do Reino microbasin, identifying two degradation classes. First, areas degraded by induced natural processes with land sliding, erosion in furrows and ravines, siltation deposits and areas subject to laminar erosion, and finally, areas degraded by occupation or inadequate soil handling: inadequate disposal of solid waste (Tab. 1), urban occupation in Permanent Preservation Areas (Fig. 4) and presence of precarious urban occupations.

Another area of this compartment that must be considered is the entrance to the tunnel of the Mário Covas Ring Highway -northern segment (Fig. 3). In December 2016, rock fall occurred in this part of the highway, which was triggered by the rock type (sheared phyllite- along the Veigas Fault, fig. 2), as well as the unfavorable direction of the tunnel excavation in relation to the orientation of the shear planes.

It is evident that the urban and road areas that underwent anthropic interventions are of low environmental quality, as a function of the produced environmental degradations. On the other hand, the preserved areas with forests, pasture/grassland areas and silviculture are of good environmental quality, attested by the water quality analyses at points 1, 2 and 4 (Azevedo et al., 2016; Oliveira et al., 2018).

In relation to Permanent Preservation Areas (PPA) of Compartment I, the PPA of Watercourses (Fig. 4) shows bigger degradation in relation to other PPA classes. This degradation was occasioned mainly by deforestation of this
Rainforest area with goal of urban area expansion and to installation of Rodoanel (a highway constructed in the perimeter of the Metropolitan Region of São Paulo to avoid that the intermunicipal traffic affects less urban roads). However the other PPA classes of Compartiment I are a little bit more preserved: the PPA of Spring (Fig. 5) shows that the springs localized in the northeast region of watershed are inside of the dense forest. In relation of PPA of declivity (Fig. 6) the most areas is localized too in the northeast region of watershed, a well preserved area. The situation of PPA of Top of the Hill (Fig. 7) is the same of PPA of declivity: the areas localized in the northeast region of watershed are being respected.

\subsection{Compartment II}

The urban class predominates in this compartment, notably on the left margin of the Cachoeirinha stream. Secondarily, silviculture, forested areas and pasture/grassland areas occur on the right margin.

The urban basic sanitation system is characterized by a high density of households with no sewer network (Fig. 3), the sanitary sewerage being via drainage and ditches (Tab. 1). The major insalubrity problem is the domestic waste system. Consequently, the assessment of the water quality at point 5 , according to the parameters used, points to a Bad (Chart 2) quality, according to Oliveira et al. (2018) and Azevedo et al. (2016).

Regarding the aspects of the physical environment, the susceptibility to mass movements and erosion is medium/high, mainly in areas of high declivity (equal or higher than 20-30\%), which make them improper for urban occupation (Andrade et al., 2008; Sato et al. 2011; Castro Gomes et al., 2011; Mesquita, 2011).

This situation is observed in the northeastern portion of this compartment. There are restricted fluvial plains along the Invernada stream (Chart 1), which are areas susceptible to flooding and inadequate for urban occupation, corroborated by the fact that these are Permanent Preservation Areas (Riverside).

The areas with low environmental quality 
correspond to the urban class, highlighting the households located along the left and right margins of the Cachoeirinha stream, in which the sanitary sewerage is very deficient, besides being areas considered inappropriate by the present Forestry Code (Fig. 4). Therefore, it is a degraded area, because of inadequate soil handling. On the other hand, in this compartment environmentally stable or regular areas represented by eucalyptus reforesting and forested areas (Fig. 3).

\subsection{Compartment III}

Structural compartment III presents physical-environmental characteristics that classify it as Area Appropriate for Occupation, according to the criteria established by Andrade (1999), notably the portions that correspond to mounds and crystalline hills (Chart 1). The areas occupied by restrict and ample fluvial plains should be protected from urban occupation, because they are susceptible to flooding (Campos, 2011; CPRM, 2015) and represent Permanent Preservation Areas (Riverside).

Even so, there are households installed on the Cachoeirinha stream margins (Fig. 3), with deficient sanitary sewerage, characterized by the lack of a sewer network and waste discharged in streams (Table 1). The bad water quality of the Cachoeirinha stream at point 6 is thus explained, yielding the following parameter values: very bad WQI; hypereutrophic TSI, and bad $\mathrm{BCl}$, as can be seen in Chart 2 (Azevedo et al., 2016; Oliveira et al., 2018).

Within the present scenario for this compartment, areas degraded by occupation or inadequate soil handling contrast with environmentally stable or regular areas. The first are represented by inadequate disposal of urban solid waste, urban occupation and rural handling in Permanent Preservation Areas and urban occupation in watershed areas. The environmentally stable areas are those preserving forests, silviculture, pasture/grassland areas and temporary cultures, with the exception of those located in PPAs.

In general, the environmental quality of this compartment is low, influenced by the lack of efficient domestic wastewater collecting and treatment systems, as well as by the inadequate anthropic occupation of the Cachoeirinha stream margins.

\subsection{Compartment IV}

This structural compartment presents as marked geomorphologic characteristic the presence of an ample fluvial plain associated with sedimentary mounds (Chart 1). From the point of view of the physical adequacy to urban settling, these two landform units yield antagonistic assessments: the first is very restrictive to occupation, in view of the organic hydromorphic soils susceptible to consolidation and prone to flooding; the second is classified as Area Proper for Occupation, when it comes to its physicalenvironmental characteristics (Andrade, 1999).

However, as seen in figure 3, urban occupation exists in both landform classes, associated with exposed soil. It characterizes degradation by urban occupation in Permanent Preservation Areas, plus the inadequate disposal of urban waste (Tab. 1). Regarding the urban basic sanitation system, besides the solid waste issue, there are households devoid of sewer network, with waste disposal in stream sand ditches.

Thus, the CIW environmental quality in its outlet is very low, due to urban occupation in areas susceptible to flooding, plus low environmental salubrity.

The anthropic occupation is consolidated in this compartment: while occupation was taking place, public managers did not pay attention to the consequences of the changes in the natural environment.

The Guarulhos Municipality, as the other municipalities of São Paulo Metropolitan Region (SPMR) and other regions of Brazil, has not been able to offer urban infrastructure in conditions adequate to the large population contingent. Studies carried out in other watersheds located in the northern portion of Guarulhos, such as Tanque Grande (Saad et al., 2013), Capão da Sombra stream (Porto, 2013), Guaraçau (Dos Santos, 2013; Ribeiro et al., 2013), Taquara do Reino stream (Vargas et al., 2015) and Ribeirão Lavras (Ribeiro, 2016), all belonging to Baquirivu-Guaçu River Watershed, attest the low environmental 
quality of their urban regions.

In the city of São Paulo, located in the Metropolitan Region of São Paulo, regions with large slopes and areas of permanent preservation (APP) were occupied irregularly (Gayoso, 2014), leading to a decrease in the environmental quality of the region, as observed in the results of this work presented in the compartment I, especially in the region of Recreio São Jorge and Novo Recreio.

Almeida (2010) describes the occupation of inadequate areas for residences near the tributaries of the Maranguapinho river Watershed, in the Metropolitan Region of Fortaleza (CE), as also observed in the occupations of compartments III and IV. These occupations of areas susceptible to natural processes like floods are more aggravated due to the precarious sanitary conditions. The worsening of environmental quality for compartments III and IV, due to lack of basic sanitation associated with high urban density, was also observed in other studies by Brazil (Dias et al., 2011; Moura et al., 2016). In a similar condition to compartment $I V$, in plain regions in developing countries, low environmental quality was observed due to lack of basic sanitation and high urban density (Phiri et al., 2005; Girija et al., 2007).

Therefore, through previous studies and based on the results obtained in this work, it can be attested that the main processes responsible for the triggering of geologic disasters in urban areas are related to inadequate land use and occupation as a consequence of the lack of basic geotechnical information on the physical environment, when it comes to urban planning. Additionally adequate basic sanitation infrastructure is not available to the population, which worsens even more the environmental salubrity of the urban areas.

\section{Conclusions}

The results obtained in this study attest that the Cachoeirinha-Invernada Watershed is largely degraded, due to urbanization characterized by high occupation densities in hills and valleys, terrains in which the physical environment is very fragile for such demand. However, in the portion that corresponds to structural compartment I, where there are preserved vegetated areas, environmentally stable or regular areas still exist.

The occupation of the Permanent Preservation Area stakes place on top of the hills, declivity, stream margins and springs.

The methods applied in the integrated assessment of the environmental quality of the Cachoeirinha-Invernada Watershed proved to be effective. In this approach, the following parameters were used: land use and occupation, water quality, urban basic sanitation system and environmental legislation.

Several authors have attributed the environmental degradation seen in the Guarulhos Municipality in its northern macro-compartment to urban expansion in this direction from the 1950's on. The urban infrastructure conditions offered to the population that occupied this macro-compartment were inadequate to reach environmental salubrity standards that would not compromise its population's health.

In effect, the lack of sanitary sewers linked to the sewer network, the disposal of wastewater directly in streams and ditches, besides the inadequate disposal of solid waste have contributed to the low environmental quality assessed in the Cachoeirinha-Invernada Watershed.

Acknowledgments. To FAPESP (São Paulo Research Foundation) for the financial support to Project 2015/05069-4.

\section{References}

Almeida, L.Q. de. 2010. Vulnerabilidades socioambientais de rios urbanos: bacia hidrográfica do rio Maranguapinho, região metropolitana de Fortaleza, Ceará. Rio Claro, 278p. Tese de doutorado. Programa de Pós-graduação em Geografia, Instituto de Geociências e Ciências Exatas, Universidade Estadual Paulista.

Andrade, M.R.M. 1999. Cartografia de Aptidão para Assentamentos Urbanos do Município de Guarulhos. São Paulo,147p. Dissertação de Mestrado. Programa de Pós-graduação em Geografia Física, Faculdade de Filosofia 
Letras e Ciências Humanas. Universidade de São Paulo.

Andrade, M.R.M., Oliveira, A.O., Queiroz, W., Sato, S.E., Barros, E.J., Bagattini, G. \& Aleixo, A.A. 2008. Aspectos Fisiográficos da Paisagem Guarulhense. In: OMAR, E.E.H. (Org.) Guarulhos tem História: questões sobre história natural, social e cultural. São Paulo, Ananda Gráfica e Editora, p. 25-46.

Azevedo, F.B., Vargas, R.R., Secco, V., Oliveira, J. \& Dalmas, F.B. 2016. Efeito do Uso e Ocupação da Terra na Comunidade de Macroinvertebrados Aquáticos na Bacia Hidrográfica Cachoeirinha Invernada, Guarulhos (SP). In: XIII SIMPÓSIO DE RECURSOS HÍDRICOS DO NORDESTE, 2016, Aracaju. Anais... Aracaju, ABRH. CDROM.

Bastos, V.S.B. \& Fonseca, L.M.G. Utilização de ferramentas de geoprocessamento para a construção de um índice de qualidade In: SIMPÓSIO BRASILEIRO DE SENSORIAMENTO REMOTO, 16, 2013, FOZ do Iguaçu. Anais... São José dos Campos, INPE, p. 1159-1166. Available at: <http://urlib. net/3ERPFQRTRW34M/3E7GLBU> Accessed on: $15^{\text {th }}$ June 2017.

Botelho, G.M. \& Silva, A.S. 2004. Bacia Hidrográfica e Qualidade Ambiental. In: VITTE, A.C. \& GUERRA, A.J.T. (Org.). Reflexões sobre a Geografia Física no Brasil. Rio de Janeiro, Ed. Bertrand Brasil, p. 153-191.

Brasil. 1984. Decreto no 89.817, de 20 de junho de 1984. Estabelece as Instruções Reguladoras das Normas Técnicas da Cartografia Nacional. Available at: < http://www.planalto.gov.br/ ccivil_03/decreto/1980-1989/D89817.htm >. Accessed on: $9^{\text {th }}$ June 2017.

Brasil. 2012. Lei n. 12.651, de 25 de maio de 2012, dispõe sobre a proteção da vegetação nativa - Código Florestal. Presidência da República Federativa do Brasil. Available at: < http://www.botuvera.sc.gov.br/wpcontent/uploads/2014/09/Lei-12651-2012C\%C3\%B3digo-Florestal.pdf >. Accessed on: $6^{\text {th }}$ June 2017.

Campos, D.C. 2011. Inundações: Problemas ou Fenômenos Naturais? A Ocupação das Várzeas dos Principais Rios no Alto Tietê e a Reprodução deste Modelo Urbano na
Bacia do Rio Baquirivu Guaçu. Guarulhos, 220p. Dissertação de Mestrado, Programa de Pós-Graduação em Análise Geoambiental, Universidade Guarulhos.

Castro Gomes, G.L.C., Oliveira, A.M.S. \& Sato, E.M. 2011. Zonas de Risco a Escorregamentos no Município de Guarulhos / SP, Brasil. Geotecnia, 119(1): 69-93.

CETESB. Companhia Ambiental do Estado de São Paulo. 2017. Relatório de Qualidade das Águas Interiores no Estado de São Paulo, 2016. São Paulo, CETESB, p. 178.

CPRM. Serviço Geológico do Brasil. 2015. Carta de Susceptibilidade a Movimentos Gravitacionais de Massa e InundaçõesMunicípio de Guarulhos - SP. Brasília, CPRM.

Christofoletti, A. 1996. Caracterização de indicadores geomorfológicos para a análise da sustentabilidade ambiental, Uberlândia/ MG. Sociedade \& Natureza, 15(1): 31-33.

Dias, F.A., Gomes, L.A. \& Alkmim J.K. 2011. Avaliação da qualidade ambiental urbana da bacia do ribeirão do Lipa através de indicadores, Cuiabá/MT, Sociedade \& Natureza, 23(1): 127 147.

Dos Santos, M.T. 2013. Análise da qualidade ambiental da bacia hidrográfica do Ribeirão Guaraçau, com base no mapa de uso da terra e aspectos morfométricos, escala 7:10.000. Guarulhos, 78p. Dissertação de Mestrado, Programa de Pós-Graduação em Análise Geoambiental, Universidade Guarulhos.

ESRI. Environmental Systems Research Institute. 2011. ArcGIS Desktop: Release 10. Redlands, Environmental Systems Research Institute.

Gayoso, R.C. 2014. Fragilidade Ambiental e Vulnerabilidade Social para análise integrada do espaço geográfico: bacia hidrográfica no Jardim Angela (São Paulo - SP). São Paulo, 148p. Dissertação de Mestrado, Programa de Pós-graduação em Geografia Física. Faculdade de Filosofia, Letras e Ciências Humanas, Universidade de São Paulo.

Girija T.R., Mahanta C. \& Chandramouli, V. 2007. Water Quality Assessment of an Untreated Effluent Impacted Urban Stream: The Bharalu Tributary of the Brahmaputra River, India. Environmental Monitoring and Assessment, 130(1): 221-236. 
Hamada N., Nessimian J.L. \& Querino R.B. 2014. Insetos aquáticos na Amazônia brasileira: taxonomia, biologia e ecologia. Manaus, INPA. 724p. Available at: < https://www.alice.cnptia. embrapa.br/handle/doc/1000609 >. Accessed on: 25th June 2017.

IBGE. Instituto Brasileiro de Geografia eEstatística. 2010. Censo Demográfico de 2010. Available at: < https://cidades.ibge.gov.br/v4/brasil/ sp/guarulhos/panorama $>$. Accessed on: $25^{\text {th }}$ February 2017.

IBGE. Instituto Brasileiro de Geografia eEstatística. 2016. Censo Demográfico de 2016. Available at: < https://cidades.ibge.gov.br/v4/brasil/ sp/guarulhos/panorama $>$. Accessed on: $20^{\text {th }}$ February 2017.

Lima, V. 2013. A sociedade e a natureza na paisagem urbana: análise de indicadores para avaliar a qualidade ambiental. Presidente Prudente, 358 p. Tese de doutorado. Programa de Pós-graduação em Geografia, Faculdade de Ciências e Tecnologia, Universidade Estadual Paulista.

Mesquita, M.V. 2011. Degradação do Meio Físico em Loteamentos nos Bairros Invernada, Fortaleza e Água Azul, como Estudos de Casos da Expansão Urbana do Município de Guarulhos (SP). Rio Claro, 146p. Tese de Doutorado, Instituto de Geociências e Ciências Exatas, Universidade Estadual Paulista.

Moura, N.S.V., Moran, E.F., Dias, T.S., Paris, G. \& Borges, F.F. 2016. Expansão urbana sobre compartimentos de relevo suscetíveis à inundação: Zona Sul do município de Porto Alegre, Rio Grande do Sul. Pesquisas em Geociências, 43(3): 299-310.

Oliveira, L.M. 2010. Acidentes Geológicos Urbanos. Curitiba: Mineropar, 78p.

Oliveira, A.M.S., Andrade, M.R.M., Sato, S.E. \& Queiroz, W. 2009. Base Geoambientais para um Sistema de Informações Ambientais do Município de Guarulhos. Guarulhos, Universidade Guarulhos (Relatório FAPESP 05/57965-1).

Oliveira, D.G., Vargas, R.R., Saad, A.R., Arruda, R.O.M., Dalmas, F.D. \& Azevedo, F.D. 2018. Land use and its reflections on the water quality of the Cachoeirinha Invernada Watershed, Guarulhos (SP). Revista Ambiente \& Água,
13(1): e2131.

Paranhos Filho A. C. 2008. Sensoriamento Remoto Ambiental Aplicado: introdução às Geotecnologias. Campo Grande, Editora UFMS, 198p.

Phiri, O., Mumba P., Moyo B.H.Z. \& Kadewa W. 2005. Assessment of the impact of industrial effluents on water quality of receiving rivers in urban areas of Malawi. International Journal of Environmental Science \& Technology, 2(3): 237-244.

Porto, A.A. 2013. Uso do solo e contaminação por esgoto do Córrego Capão da Sombra, Guarulhos, SP. Guarulhos, 89p. Dissertação de Mestrado, Programa de Pós-graduação em Análise Geoambiental. Universidade Guarulhos.

Ribeiro, B.M.G. \& Mendes, C.A.B. 2015. Índice de Qualidade Ambiental Urbano: uma proposta metodológica aplicada a áreas urbanas de ocupação irregular. XVII SIMPÓSIO BRASILEIRO DE SENSORIAMENTO REMOTO, XVII, 2015, João Pessoa. Anais... João Pessoa, INPE. Available at: < http://www.dsr.inpe.br/ sbsr2015/files/p1421.pdf $>$. Accessed on 20 th June 2017

Ribeiro, T.F.B. 2016. Reflexos do uso da terra na avaliação da poluição hídrica da bacia hidrográfica do Ribeirão das Lavras, Guarulhos - SP. Guarulhos, 122p. Dissertação de Mestrado, Programa de Pós-graduação em Análise Geoambiental. Universidade Guarulhos.

Ribeiro, T.F.B., Andrade, M.R.M., Sato, S., Santos, A.M. \& Saad A.R. 2013. A. Análise geoambiental da bacia hidrográfica do Ribeirão Guaraçau, Guarulhos (SP), com base no mapa de uso da terra e aspectos morfométricos. Revista Geociências, 12 (1): 49-62.

Saad, A.R., Vargas, R.R., Lopes, J.C., Arruda, R. O.M. \& De Queiroz, W. 2013. Índice de estado trófico da bacia hidrográfica do Ribeirão Tanque Grande, Guarulhos (SP): análise comparativa entre as zonas rural e urbana. Geociências, 32(4): 611-624.

Sato, E.M., Oliveira, A.M.S., Sayawa, S.B., Herling, T.B.R., Moretti, R.S. \& Gomes, G.L.C.C. 2011. Estudo de Urbanização em Áreas de Risco a Escorregamentos nos Loteamentos do 
Recreio São Jorge e Novo Recreio, Região do Cabuçu, Guarulhos (SP), Brasil. Paisagem e Ambiente, 29(1): 57-82.

Tominaga, L.K., Santoro, J. \& Amaral, R. 2012. Desastres Naturais: Conhecer para Prevenir. São Paulo, Instituto Geológico, 196p.

Vargas R.R., Saad A.R., Dalmas F.B., Rosa A., Arruda R.O.M., Mesquita M.V. \& Andrade M.R.M. 2015. Water Quality Assessment in the Córrego Taquara do Reino Hydrographic Basin, Guarulhos Municipality (São Paulo State Brazil): Effects of Environmental Degradation. Anuário do Instituto de Geociências, 38(2): 137-144.

Zombini, E.V. \& Pelicioni, M.C.F. 2014. Saneamento Básico para a Saúde Integral e a Conservação do Ambiente. Educação Ambiental e Sustentabilidade. In: Philippi Jr A. \& Pelicioni, M. C. F. (Eds). Educação Ambiental e Sustentabilidade. $2^{a}$ ed., São Paulo, Manole, 877p.

WHO - World Health Organization. 2006. The World Health Report 2006 - working together for health. Available at: < https://www.who.int/ whr/2006/en/ >. Acessed on: 20 th February 2017. 